\title{
Implementasi Algoritma Gosip Dalam Jaringan Peer-to-Peer
}

\author{
Aditya Nugraha Tama ${ }^{1}$, Saptadi Nugroho ${ }^{2}$, Hartanto Kusuma Wardana ${ }^{3}$ \\ Program Studi Sistem Komputer, \\ Fakultas Teknik Elektronika dan Komputer, \\ Universitas Kristen Satya Wacana, Salatiga \\ 1622013002@student.uksw.edu, 2saptadi.nugroho@staff.uksw.edu, \\ 3hartanto.kusuma@staff.uksw.edu
}

\section{Ringkasan}

Komputer merupakan perangkat yang dapat melakukan banyak hal, termasuk berkomunikasi satu sama lain. Seperti halnya manusia dengan pengaturan yang tepat komputer bisa mendapatkan suatu informasi terkait suatu data melalui proses komunikasi. Oleh sebab itu, diperlukan sebuah protokol jaringan yang dapat mengatur bagaimana komputer dapat tehubung satu sama lain serta mengatur proses pertukaran data. Algoritma gosip merupakan algoritma yang mengatur proses pertukaran data antar dua buah node yang terhubung. Untuk mengimplementasikan algoritma gosip terdapat dua hal yang paling utama yaitu active thread dan passive thread. Active thread diawali saat proses menghubungi node tetangga untuk diajak bertukar data dijalankan, sedangkan passive thread akan menunggu sampai ada ajakan dari tetangga. Pengujian yang telah dilakukan dengan dua buah node adalah pengujian proses komunikasi antar node dan proses pertukaran serta update data. Dari hasil pengujian, proses komunikasi dan pertukaran serta update data dapat berjalan baik dan lancar.

Kata kunci: algoritma gosip, protokol, jaringan

\section{Pendahuluan}

Kemajuan teknologi di bidang komputer yang semakin pesat, membuat banyak hal dalam kehidupan menjadi serba mudah. Komputer dapat membantu bahkan mengerjakan tugas manusia seperti, mengolah serta menganalisis data, mengendalikan serta mengatur proses produksi, dan terhubung dengan milyaran komputer lain yang tersebar di seluruh dunia melalui jaringan internet. Melalui internet, komputer dapat melakukan pertukaran data dengan memenuhi suatu protokol komunikasi yang ada. Dengan kata lain, komputer satu dengan komputer lain dapat melakukan proses komunikasi layaknya manusia.

Dalam kehidupan, manusia pasti melakukan proses komunikasi dengan orang lain. Salah satu bentuk komunikasi yang dilakukan oleh manusia adalah bergosip. Gosip merupakan salah satu cara komunikasi yang digemari manusia, dimana telah dilakukan sejak jaman Romawi sampai dengan sekarang [1]. Ketika manusia bergosip akan terjadi proses pertukaran informasi, sehingga bisa didapatkan suatu informasi baru yang belum diketahuinya. Walaupun informasi yang didapatkan belum tentu kebenarannya, gosip dapat menyebar dengan cepat. Hal inilah yang kemudian memicu para ilmuwan untuk membuat komputer dapat menyebarkan informasi layaknya manusia bergosip. 


\section{Dasar Teori}

\subsection{Algoritma Gosip}

Awal mula dari algoritma gosip adalah untuk menghitung jumlah panggilan telepon yang dibutuhkan untuk membuat semua wanita mengetahui gosip yang sama, ketika terdapat sejumlah $n$ wanita yang mengetahui suatu informasi yang tidak diketahui oleh wanita lain. Mereka berkomunikasi melalui telepon, dan saat seorang wanita menelpon wanita lain mereka akan saling bertukar informasi [2]. Berbeda dengan algoritma flooding yang murni, gosip mengurangi jumlah operasi per node per satuan waktu, mengurangi konsumsi daya per node, dan jumlah total transmisi dalam satuan waktu (menguragi interferensi), yang membuatnya sangat sesuai bila digunakan untuk suatu proses komunikasi jaringan [3][4]. Algoritma gosip merupakan salah satu metode komunikasi kuno yang penting pada jaringan yang besar, dan telah dipelajari dengan berbagai macam istilah lain seperti rumor spreading, information dissemination, dan broadcasting [5].

\subsection{Peer-to-Peer}

Jaringan peer-to-peer (P2P) adalah jaringan dimana semua node dapat bertindak sebagai client/server, karena saling terhubung secara langsung satu sama lain. Selain itu, dalam jaringan P2P tidak terdapat titik pengaturan yang terpusat. Daya tarik utama dari jaringan P2P adalah dapat berbagi sumber daya terdistribusi, sehingga menghindari duplikasi dan biaya tambahan. Satu atau lebih komputer dapat berbagi file, printer, drive optik dan sumber daya lain [6].

\section{Perancangan}

\subsection{Gambaran Sistem}

Pada setiap node terdapat tiga hal penting yaitu active thread, passive thread, serta data yang digunakan dalam proses komunikasi.

Node 1

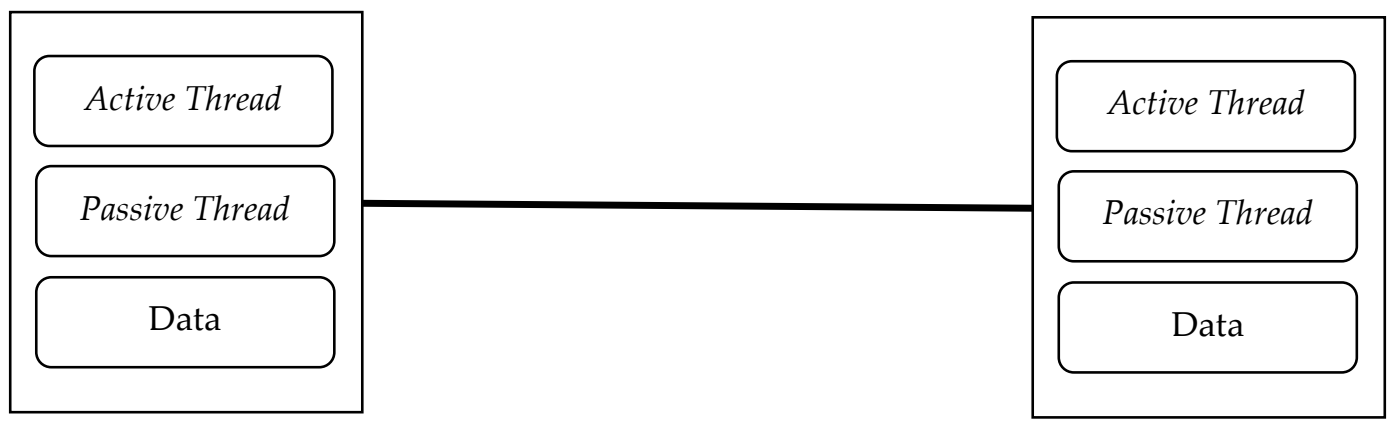

Gambar 1. Gambaran Sistem

Node akan secara otomatis menjalankan passive thread sehingga setiap node selalu menunggu dan mengecek apakah ada kiriman dari node lain, ketika terdapat kiriman maka node akan membalas kiriman tersebut dengan data miliknya. Sedangkan active thread dijalankan ketika node memulai proses pertukaran data, yaitu ketika data dikirim ke node tetangga[7]. 


\subsection{Active Thread}

Active thread diawali dengan menunggu selama selang waktu yang ditentukan, kemudian menjalankan fungsi pemilihan tetangga. Karena hanya terdapat dua buah node, maka IP address tetangga dapat dimasukkan secara manual. Kemudian, data akan dikirimkan kepada IP tersebut. Ketika ada data balasan dari tetangga, maka terima data, kemudian hitung rata-rata dan update data. Jika tetangga tidak membalas, maka ulangi proses dari awal. Pada sistem ini active thread bekerja secara terus-menerus (perulangan tak terbatas).

\subsection{Passive Thread}

Saat passive thread dijalankan, maka node akan menunggu untuk dihubungi oleh node lain. Jika ada node yang menghubungi dan kiriman data diterima, kemudian node tersebut akan menyimpan kiriman data tersebut, lalu akan mengirim datanya sebagai balasan. Kemudian, rata-rata akan dihitung dari penjumlahan dari data yang diterima dengan data sendiri dibagi dengan dua. Setelah menghitung rata-rata, maka data dari node akan di update.

\subsection{Realisasi Sistem}

Untuk merealisasikan sistem dibutuhkan alat-alat berupa Raspberry Pi sebagai node dan kabel ethernet untuk meyambungkan 2 buah node. Prefix yang digunakan dalam jaringan ini adalah /24. Sehingga dalam satu jaringan terdapat 254 host yang dapat digunakan. Jaringan yang digunakan berada pada kelas C. Pemberian IP address dalam sistem ditunjukkan dalam Tabel 1.

Tabel 1. Pembagian IP Address Pada Sistem

\begin{tabular}{|c|c|c|}
\hline Nama & Network ID & IP Address \\
\hline Node 1 & $192.168 .30 .0 / 24$ & 192.168 .30 .2 \\
\hline Node 2 & $192.168 .30 .0 / 24$ & 192.168 .30 .20 \\
\hline
\end{tabular}

\section{Pengujian dan Analisis}

Dari hasil implementasi maka dapat dilakukan proses pengujian pada proses komunikasi yang terbentuk antara dua buah node dan pertukaran serta update data. Data awal dari node 1 bernilai 10, sedangkan node 2 bernilai 20. Pada Gambar 2. Terlihat bahwa node 1 mengirimkan data awalnya yang bernilai 10 kepada node 2 yang memiliki IP address 192.168.30.20. Kemudian dari Gambar 3. Terlihat bahwa node 2 telah menerima data yang bernilai 10, lalu data tersebut disimpan. Kemudian, node 2 membalas dengan data awal miliknya yang bernilai 20. Proses selanjutnya yang terjadi pada node 2 adalah menghitung rata-rata dari data yang diterima dengan data miliknya yang akan digunakan sebagai data yang dikirimkan pada proses pengiriman selanjutnya. Kembali pada node 1 setelah menerima balasan data yang bernilai 20 dari node 2 maka proses selanjutnya adalah menghitung rata-rata dari data yang diterima dengan data miliknya yang akan digunakan sebagai data yang dikirimkan pada proses pengiriman selanjutnya. Sehingga kedua node sepakat terhadap bahwa data bernilai 15. 


\section{pi@raspberrypi: /Desktop/GOSIP}

\section{File Edit Tabs Help}

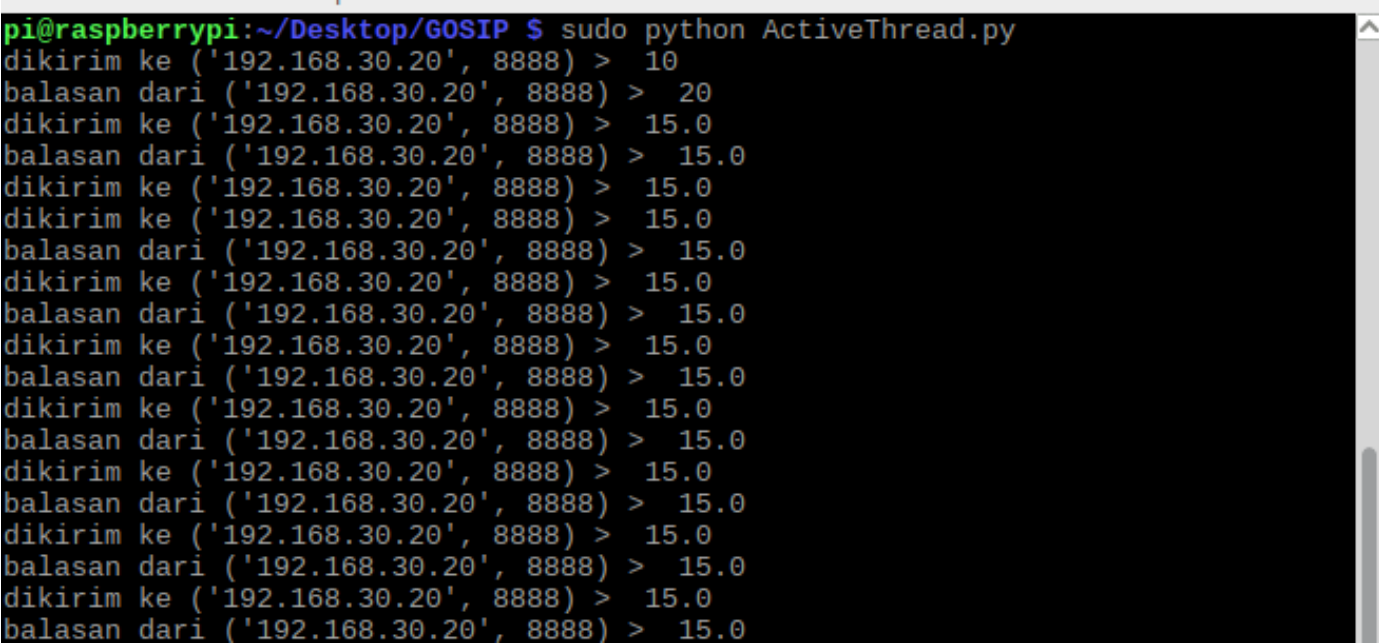

Gambar 2. Tampilan Active Thread Node 1

\section{pi@raspberrypi: /Desktop/GOSIP}

File Edit Tabs Help

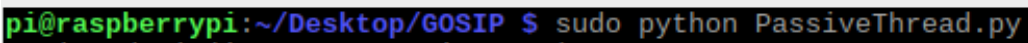

terima dari ('192.168.30.2', 9999) > 10

dibalas $>20$

terima dari ('192.168.30.2', 9999) > 15.0

dibalas > 15.0

terima dari ('192.168.30.2', 9999) > 15.0

dibalas > 15.0

terima dari ('192.168.30.2', 9999) > 15.0

dibalas > 15.0

terima dari ('192.168.30.2', 9999) > 15.0

dibalas > 15.0

terima dari $(' 192.168 .30 .2 ', 9999)>15.0$

dibalas > 15.0

terima dari ('192.168.30.2', 9999) > 15.0

dibalas > 15.0

terima dari $\left({ }^{\prime} 192.168 .30 .2 ', 9999\right)>15.0$

dibalas > 15.0

terima dari ('192.168.30.2', 9999) > 15.0

dibalas > 15.0

terima dari ('192.168.30.2', 9999) > 15.0

dibalas $>15$.

Gambar 3. Tampilan Passive Thread Node 2

\section{Kesimpulan}

Implementasi algoritma gosip dapat dilakukan pada dua buah Raspberry Pi yang berfungsi sebagai node yang terhubung secara peer-to-peer. Node satu dengan yang lain dapat saling berkomunikasi untuk bertukar data. Proses pengiriman dan pembaruan data pada tiap node berjalan dengan baik. Hal ini dibuktikan dengan data yang bernilai sama saat node saling terhubung.

\section{Daftar Pustaka}

[1] M. Crescimbene, F. Longa, and T. Lanza, The Science of Rumors, Roma: Annals of Geophysics, h. 421-425, 2012. 
[2] B. Baker and R. Shostak, Gossip and Telephones, North Holland Publishing Company, h. 191-193, 1971.

[3] S. Boyd, Arpita Ghosh, et al., "Analysis and optimization of randomized gossip algorithms", IEEE Trans. on Inf. Theory, Vol. 52, No. 6, 2004.

[4] L. Alvisi, et al., "How robust are gossip-based communication protocols?" $A C M$ SIGOPS Operating Systems Review, h. 14-18, 2007.

[5] Z. Guo and H. Sun, "Gossip vs. Markov Chains, and Randomness-Efficient Rumor Spreading," SODA '15 Proceedings of the twenty-sixthannual ACM-SIAM symposium on Discrete algorithms, h. 411-430, 2015.

[6] B. Sosinsky, Networking Bible, Indiana: Wiley Publishing Inc., 2009.

[7] R. Bakhshi, D. Gavidia, et al., "A modeling framework for gossip-based information spread", In Quantitative Evaluation of Systems (QEST) 2011 Eighth International Conference, h 245-254, 2011. 
